\title{
IMPLEMENTASI PERENCANAAN KURIKULUM PENDIDIKAN ANAK USIA DINI PADA TAMAN KANAK-KANAK AISYIYAH BUSTANUL ATHFAL KOTA PALOPO
}

\author{
Duriani \\ Program Pascasarjana Doktor Pendidikan dan Keguruan \\ Universitas Islam Negeri Alauddin Makassar \\ Email: duriani.plp@gmail.com
}

\begin{abstract}
Abstrak
Penelitian ini bertujuan untuk mengetahui bagaimana implementasi perencanaan kurikulum Taman Kanak-Kanak Aisyiyah Bustanul Athfal terintegrasi dengan pendidikan al-Islam Kemuhammadiyahan. Penelitian ini merupakan penelitian kualitatif yakni melakukan penelitian langsung kelapangan dengan obyek penelitian Taman Kanak-Kanak Aisyiyah Bustanul Athfal Kota Palopo menggunakan pendekatan kearifan lokal dalam menerapkan kurikulum terintegrasi dengan pendidikan al-Islam Kemuhammadiyahan. Teknik yang digunakan dalam mengambil data adalah observasi, wawancara, dan dokumentasi, sedangkan pengukuran kredibilitas data menggunakan triangulasi. Hasil penelitian menunjukkan perencanaan pembelajaran kurikulum Taman Kanak-Kanak Aisyiyah Bustanul Athfal Kota Palopo meliputi Rencana Kegiatan Semester, Rencana Kegiatan Mingguan dan Rencana Kegiatan Harian dan Evaluasi sebagai tahap akhir dalam penilaian hasil belajar anak didik dan alokasi waktu yang digunakan dalam 2 Semester selama 34 minggu merupakan program tahunan diuraikan dalam Tema Diriku, Keluargaku, Lingkungan, Binatang, Tanaman, Kendaraan, Alam Semesta, Negaraku dijabarkan ke dalam berbagai sub tema dalam berbagai lingkungan perkembangan anak meliputi aspek nilai agama dan moral, aspek sosial emosional, aspek kognitif, aspek bahasa dan aspek seni terintegrasi dengan pendidikan al-Islam Kemuhammadiyahan melalui pendekatan kearifan lokal dalam menanamkan nilainilai akidah, ibadah, akhlak dan muamalah pada diri anak sejak usia dini.
\end{abstract}

Kata Kunci: Perencanaan Kurikulum, Pendidikan Anak Usia Dini, Al-Islam Kemuhammadiyahan

\begin{abstract}
This study aims to find out how the implementation of Taman Kanak-Kanak Aisyiyah Bustanul Athfal curriculum planning is integrated with Kemuhammadiyahan's alIslam education. This research is a qualitative research that is conducting direct research in the field with the research object of Taman Kanak-Kanak Aisyiyah Bustanul Athfal in Palopo City using a local wisdom approach in implementing an integrated curriculum with al-Islam education in Kemuhammadiyahan. The technique used in retrieving data is observation, interviews, and documentation, while measuring the credibility of the data using triangulation. The results of the study showed that the learning planning curriculum of Taman Kanak-Kanak Aisyiyah Bustanul Athfal curriculum included Semester Activity Plans, Weekly Activity Plans
\end{abstract}


and Daily Activity Plans and Evaluation as the final stage in evaluating student learning outcomes and the time allocation used in 2 Semesters for 34 weeks was The annual program described in the Theme of Myself, My Family, Environment, Animals, Plants, Vehicles, Universe, My Country is translated into various sub-themes in various children's development environments including aspects of religious and moral values, social emotional aspects, cognitive aspects, language aspects and aspects art integrated with al-Islam education Kemuhammadiyahan through a local wisdom approach in instilling the values of aqeedah, worship, morals and muamalah in children from an early age.

Keywords: Curriculum Planning, Early Childhood Education, Al-Islam Kemuhammadiyahan

\section{PENDAHULUAN}

Taman Kanak-Kanak merupakan pendidikan anak usia dini pada jalur pendidikan formal bertujuan membantu anak didik mengembangkan berbagai potensi, baik psikis dan fisik mencakup aspek nilai agama dan moral, sosial emosional, kemandirian, kognitif, bahasa, fisik motorik, untuk menempuh pendidikan selanjutnya. Aisyiyah sebagai gerakan perempuan Muhammadiyah yang berdiri pada tanggal 17 Mei 1917 Masehi. telah menyelenggarakan Pendidikan Anak Usia Dini diberi nama Taman Kanak-Kanak Aisyiyah Bustanul Athfal pada tahun 1919 M, disingkat TK. ABA berfungsi untuk membina, menumbuhkan dan mengembangkan seluruh potensi anak usia dini secara optimal sehingga terbentuk watak, karakter, sikap yang mampu berperilaku akhlakul karimah. Menurut Tarazi (2003) dalam bukunya The Child in Islam: A Muslim Parent's Handbook, bahwa apabila anak dibesarkan dengan bimbingan akhlak yang mulia dari orang tua dan lingkungan yang kondusif maka akan memiliki banyak figur untuk diteladani dan membantu dalam pembentukan pribadi yang Islami.

Kurikulum dan Model Pembelajaran yang diterbitkan oleh Pimpinan Pusat Aisyiyah (2012) bahwa visi utama pendidikan Taman Kanak-Kanak Aisyiyah Bustanul Athfal adalah terciptanya sistem pendidikan anak usia dini yang kondusif, demokratis, Islami dan di ridhoi oleh Allah swt. Langkah yang dilakukan Aisyiyah untuk pencapaian visinya adalah membekali perkembangan anak dengan keimanan sehingga anak menjadi anak yang beriman dan bertaqwa, mengembangkan potensi anak sedini mungkin, menciptakan suasana kondusif dan demokratis dalam perkembangan dan pertumbuhan anak.

Tujuan Pendidikan Taman Kanak-Kanak Aisyiyah Bustanul Athfal adalah Pertama, menanamkan benih-benih keimanan dan ketaqwaan kepada Allah swt sedini mungkin dalam kepribadian anak yang terwujud dalam perkembangan kehidupan jasmani dan rohani anak sesuai dengan tingkat perkembangannya. Kedua, bertujuan mendidik anak berakhlak mulia, cakap, percaya diri dan berguna bagi masyarakat, bangsa dan negara.Ketiga, membantu mengembangkan seluruh potensi dan kematangan fisik, intelektual, emosional, moral dan agama secara

2 NANAEKE - Indonesian Journal of Early Childhood Education, Vol. 1, No. 1, Desember 2018 
optimal dalam lingkungan pendidikan yang kondusif, demokratis dan kompetetitif.

Salah satu program pendidikan dicanangkan oleh Aisyiyah dalam Tanfidz Muktamar Aisyiyah ke 47 tahun 2010 adalah meningkatnya Taman Kanak-Kanakan penyelenggaraan Pendidikan Anak Usia Dini diarahkan pada pencerdasan, pembentukan karakter utama, dan pemandirian, agar menjadi manusia bertaqwa, berilmu, terampil, berkepribadian, mandiri dan tanggung jawab dalam kehidupan pribadi, keluarga, masyarakat, bangsa dan ummat manusia. Meningkatkan kualitas Pendidikan Anak Usia Dini khususnya revitalisasi Taman Kanak-Kanak Aisyiyah melalui berbagai pendekatan dan model percontohan yang memiliki ciri khas Aisyiyah sehingga dapat bersaing dengan lembaga pendidikan lain.

Upaya Aisyiyah Kota Palopo untuk membantu memenuhi kebutuhan anak usia dini pada bidang pendidikan yakni berusaha menfasilitasi dan mengembangkan Kurikulum Taman Kanak-Kanak yang dapat memberikan pendidikan berkualitas pada anak usia dini, khususnya Taman Kanak-Kanak Aisyiyah Bustanul Athfal Kota Palopo. Disisi lain Kompleksitas kehidupan masyarakat yang dinamis, merupakan tantangan tersendiri bagi organisasi perempuan Muhammadiyah untuk terus menggulirkan komitmen dan kontribusinya terhadap dunia pendidikan dengan menyusun kurikulum dan model pembelajaran terintegrasi dengan al-Islam Kemuhammadiyahan yang menggunakan kearifan lokal dalam pencapaian tujuan pendidikan Taman Kanak-Kanak Aisyiyah Bustanul Athfal yakni menanamkan benihbenih keimanan dan ketakwaan kepada Allah swt. sedini mungkin dalam kepribadian anak, mendidik anak berakhlakul karimah dan mampu mengembangkan seluruh potensi yang dimiliki secara optimal dalam lingkungan yang kondusif. Sasaran utama pendidikan di Taman Kanak-Kanak Aisyiyah Bustanul Kota Palopo dalam Tanfidz Muktamar Aisyiyah ke 47 (2010) adalah membangun individu yang berkepribadian Islami berdasarkan pada Al-Qur'an dan Sunnah Rasulullah saw.

Peraturan Pemerintah No. 17 tahun 2010 menjelaskan tentang Pengelolaan dan Penyelenggaraan Pendidikan serta Program yang diterapkan pada lembaga Taman Kanak-Kanak Aisyiyah Bustanul Athfal mengacu pada nomor 137 tahun 2014 tentang standar Pendidikan Anak Usia Dini, kurikulum Taman Kanak-Kanak Aisyiyah diintegrasikan dengan pendidikan al-Islam Kemuhammadiyahan serta pendidikan budaya/karakter bangsa sesuai dengan perkembangan anak. Taman Kanak-Kanak Aisyiyah Kota Palopo sebagai salah satu lembaga/amal usaha Aisyiyah telah melaksanakan proses pembelajaran mengacu pada kurikulum dan model pembelajaran Taman Kanak-Kanak Aisyiyah Bustanul Athfal. Menurut Trianto (2011) pendidikan tersebut bertujuan untuk memfasilitasi pertumbuhan dan perkembangan anak secara menyeluruh atau menekankan pada pengembangan seluruh aspek kepribadian anak.

Salah satu usaha untuk memberikan pendidikan dan membantu perkembangan anak usia dini, baik dari segi kecerdasan dan keterampilan, sejak dini melalui penanaman kebiasaan-kebiasaan positif yang merupakan pilar terkuat 
untuk pendidikan anak usia dini, dan metode paling efektif dalam membentuk iman anak dan meluruskan akhlak.Program pembelajaran di Taman Kanak- Kanak Aisyiyah Bustanul Athfal mencakup bidang pengembangan pembentukan perilaku dan pengembangan kemampuan dasar dilaksanakan melalui kegiatan bermain, bertahap, berkesinambungan dan bersifat pembiasaan.

Berdasarkan hal tersebut maka kurikulum Taman Kanak-Kanak Aisyiyah yang berciri khas al-Islam Kemuhammadiyahan yang diimplementasikan oleh Taman Kanak-Kanak Aisyiyah Bustanul Athfal Kota Palopo menggunakan pendekatan kearifan lokal melalui pappaseng para leluhur dalam menanamkan nilai religius pada anak sejak usia dini meliputi nilai mappesona ri dewata seuwae, nilai alempureng, nilai Agettengeng, dan nilai Aperrukeng sebagai bentuk penanaman akidah, ibadah, akhlak dan muamalah duniawiyah. Pada dasarnya dalam mengimplementasikan Kurikulum dan model pembelajaran Taman Kanak-Kanak Aisyiyah Bustanul Athfal sudah dilaksanakan oleh Taman Kanak-Kanak Aisyiyah Bustanul Athfal Kota Palopo namun belum terlaksana secara optimal dan perlu peningkatan dalam pencapaian standar Pendidikan Anak Usia Dini.

Dari permasalahan tersebut maka penelitian ini memiliki rumusan masalah yakni bagaimana perencanaan pembelajaran kurikulum Taman Kanak-Kanak Aisyiyah Bustanul Athfal Kota Palopo. Oleh karena itu penelitian ini bertujuan untuk mengetahui implementasi perencanaan kurikulum Pendidikan Anak Usia Dini pada Taman Kanak-Kanak Aisyiyah Bustanul Athfal Kota Palopo.

\section{METODE PENELITIAN}

Penelitian ini merupakan penelitian kualitatif jenis penelitian studi kasus dilakukan terhadap peristiwa atau gejala yang sedang berlangsung (ex facto). Peneliti melakukan penelitian langsung kelapangan pada Taman Kanak-Kanak Aisyiyah Bustanul Athfal I-IV Kota Palopo. Peneliti sendiri sebagai intrumen kunci dalam penelitian ini. Penelitian ini dilakukan menggunakan wawancara langsung pada kepala Sekolah, pengelola, guru Taman Kanak-Kanak sebagai data sekunder dan informan lainnya yang terkait dengan penelitian. Data yang sudah dikumpulkan dianalisis mengunakan analisis deskriptif. Pelaksanaan teknik pemeriksaan keabsahan data dalam penelitian ini didasarkan pada kriteria tertentu. Dalam pengujian keabsahan data, metode penelitian kualitatif meliputi uji, credibility (validitas internal), transferability (validitas ekternal), dependability (reliabilitas), dan confirmability (obyektivitas). Uji kredibilitas data atau kepercayaan terhadap hasil penelitian kualitatif antara lain dilakukan dengan perpanjangan pengamatan, peningkatan ketekunan dalam penelitiaan, diskusi dengan teman sejawat.

\section{HASIL DAN PEMBAHASAN}

Implementasi Kurikulum Taman Kanak-Kanak Aisyiyah Bustanul Athfal dengan kurikulum berbasis kompetensi mencakup perencanaan pengembangan program,

4 NANAEKE - Indonesian Journal of Early Childhood Education, Vol. 1, No. 1, Desember 2018 
pelaksanaan pembelajaran dan evaluasi pembelajaran dalam mencapai tujuan pendidikan. Tujuan ini dipandang sebagai strategi untuk mencapai tujuan pendidikan nasional yakni mencerdaskan kehidupan bangsa dan mengembangkan manusia Indonesia seutuhnya yaitu manusia yang beriman dan bertaqwa dan berbudi pekerti luhur yang memiliki pengetahuan dan keterampilan, kesehatan jasmani dan rohani, kepribadian yang mantap dan mandiri. Menurut Hamalik (2008), Kurikulum sebagai suatu sistem keseluruhan memiliki komponen-komponen yang berkaitan satu dengan yang lain yakni: tujuan, materi, metode, organisasi dan evaluasi. Komponen tersebut, baik secara sendiri-sendiri maupun secara bersamasama menjadi dasar utama dalam upaya mengembangkan sistem pembelajaran.

Standar proses kegiatan pembelajaran Taman Kanak-Kanak Aisyiyah Bustanul Athfal terdiri atas: Pertama, perencanaan pembelajaran dilakukan dengan membuat perencanaan semester, RKM, dan RKH dan penilaian sesuai dengan pertumbuhan dan perkembangan anak, Kedua pengorganisasian meliputi pemilihan metode yang tepat bervariasi, pemilihan alat bermain dan sumber belajar yang ada dilingkungan, pemilihan teknik dan alat penilaian sesuai dengan kegiatan yang dilaksanakan. Menurut Muflihin (2015) bahwa Perencanaan adalah kegiatan berupa persiapan menyusun langkah-langkah pelaksanaan suatu pekerjaan atau penyelesaian suatu masalah dalam bidang pendidikan secara terarah sesuai dengan tujuan pendidikan yang telah ditetapkan. Menurut Sukmadita (2011) bahwa Komponen kurikulum PAUD terdiri dari STTPA, kompetensi Inti, kompetensi dasar, alokasi waktu, indikator capaian perkembangan (ICP), program pembelajaran (program tahunan, program semester, RPPM, RPPH, identitas Variabel bebas merupkan proses perencanaan pembelajaran PAUD.

Perencanaan Pembelajaran Kurikulum Taman Kanak-Kanak Aisyiyah Bustanul Athfal Palopo mencakup Rencana Kegiatan Semester, Rencana Kegiatan Mingguan dan Rencana Kegiatan Harian dan Evaluasi sebagai tahap akhir dalam penilaian hasil belajar anak didik. Keseluruhan kegiatan tersebut tercakup pada kegiatan semester yang diuraikan sebagai berikut: Tema semester I meliputi diriku, lingkungan, binatang, tanaman, dan rekreasi, pekerjaan, air/udara/api, negara dan alam semester diprogramkan pada semester II, dijabarkan ke dalam berbagai sub tema. Strategi Pembelajaran yang digunakan dalam (Rencana Kegiatan semester Taman Kanak-Kanak Aisyiyah Kota Palopo) dengan metode bercakap-cakap, tanya jawab langsung, bercerita, menyanyi, pemberian tugas, demonstrasi, karyawisata, evaluasi dan penilaian hasil pembelajaran dengan pemberian penugasan, unjuk kerja, dan hasil karya anak didik. Selanjutnya alokasi waktu yang digunakan dalam 2 Semester selama 34 minggu merupakan program tahunan.

Tema yang diprogramkan terintegrasi dengan al-Islam Kemuhammadiyahan dijabarkan dalam pengamalan nilai budaya pangadereng Taman Kanak-Kanak Aisyiyah Bustanul Athfal Kota Palopo mengandung nilai Dewata Seuwae, nilai kejujuran/allempureng, nilai kecerdasan/amaccangan, nilai keteguhan/ 
agettengeng, nilai peduli/aperrukeng, sebagai cerminan penanaman akidah, ibadah, muamalah dan akhlak peserta didik. Kompetensi inti yang digambarkan dalam struktur program pembelajaran pada kurikulum Taman Kanak-Kanak Aisyiyah merupakan gambaran pencapaian standar tingkat pencapaian perkembangan anak pada usia 6 tahun, mencakup kemampuan sikap spritual, sikap sosial, pengetahuan dan keterampilan.

Peneliti dapat mengungkapkan bahwa penanaman sikap menjadi proritas utama dibandingkan dengan pengembangan pengetahuan dan keterampilan. Kompetensi inti (KI-1) terkait dengan sikap spritual, sasarannya adalah bagaimana peserta didik dapat menerima ajaran agama yang dianutnya sebagai bentuk pengamalan nilai keimanan pada diri anak sejak dini dengan mengenal Allah swt. melalui ciptaan-Nya, anak dapat mengucapkan dua kalimah syahadat, mengetahui nama agama, Tuhan, Nabi dan kitab suci.

Pengamalannya dilakukan menggunakan model pembelajaran tematik integratif dengan al-Islam Kemuhammadiyahan mengandung nilai Dewata SeuwaE dan nilai agettengen. Menurut Haddade (1986) salah satu pappaseng dari orang bugis tentang ketauhidan yaitu: Alliruko ri Puang Allah Ta'ala, maraja adape ri lino nennia ri akhera (berlindunglah kepada Allah, karena Allah Maha pemberi ampun di dunia dan akhirat). Sebagaimana firman dalam QS an-Nisa/4: 36:

Terjemahnya:

Sembahlah Allah dan janganlah kamu mempersekutukan-Nya dengan sesuatupun....

Ayat tersebut menggambarkan bahwa perlunya penanaman nilai keimanan pada anak sejak usia dini untuk memantapkan keyakinan anak terhadap eksistensi Allah sebagai satu-satunya yang patut disembah di muka bumi ini.

Nilai agettengeng merupakan sikap keteguhan atau sikap istiqamah didasarkan pada penyerahan diri atas segala akibat yang ditimbulkan Allah. Perintah beristiqamah dinyatakan dalam QS Hud/11: 112:

Terjemahnya:

Maka tetaplah kamu pada jalan yang benar, sebagaimana diperintahkan kepadamu dan (juga) orang yang telah taubat beserta kamu dan janganlah kamu melampaui batas. Sesungguhnya Dia Maha melihat apa yang kamu kerjakan.

Menurut Gani (1990) penanaman nilai keimanan dan keteguhan dapat dijabarkan oleh guru Taman Kanak-Kanak Aisyiyah dengan memperhatikan pappasengbahwa ada 3 hal yang harus dijadikan prinsip dalam hidup ini (Tellu Riala Sappo) yaitu Tauwe ri Dewata dengan mengajarkan anak agar selalu merasa takut kepada Tuhan-Nya, (Siri'e Riwatakkaleta), malu pada dirinya sendiri dan (Siri'e ri Padatta Tau) malu kepada sesamanya manusia sebagai hamba Allah.

Kedua, Kompetensi inti-2 diharapkan dapat membentuk anak didik agar

6 NANAEKE - Indonesian Journal of Early Childhood Education, Vol. 1, No. 1, Desember 2018 
mampu memiliki prilaku hidup sehat, rasa ingin tahu, kreatif dan estetis, percaya diri, disiplin, mandiri, peduli, mampu menyesuaikan diri dan toleran kepada orang lain, mampu menyesuaikan diri, tanggung jawab, jalur, rendah hati dan santun dalam berinteraksi dengan keluarga, pendidik, dan teman, sebagai bentuk pencapaian kemampuan sikap sosial.

Hal ini mengandung nilai Aperrukeng (rasa solider, peduli pada sesama manusia) merupakan sikap yang penting ditanamkan dalam diri sang anak sejak usia dini sehingga memiliki rasa kekeluargaan yang tinggi, cepat peduli, saling tolong menolong sebagai bentuk ikatan jalinan persaudaraan yang kuat dan harus dipelihara terus menerus, untuk menjaga persatuan, kesatuan dan menangkal perpecahan diantara manusia. Ditegaskan dalam QS al-Hujurat/49:10:

Terjemahnya:

Orang-orang beriman itu Sesungguhnya bersaudara. sebab itu damaikanlah (perbaikilah hubungan) antara kedua saudaramu itu dan takutlah terhadap Allah, supaya kamu mendapat rahmat.

Ayat tersebut di atas menunjukkan sikap sosial sebagai cerminan perilaku rasa peduli, mandiri, rasa ingin tahu, disiplin, percaya diri sebagai wujud terjalin hubungan kekeluargaan/persaudaaran yang kuat diantara anak didik dalam hubungan sesama manusia.

Ketiga, Kompetensi Inti (KI-3) terwujud pada perkembangan anak didik untuk mengenali diri, keluarga, teman, pendidik, lingkungan sekitar, agama, teknologi, seni dan budaya di rumah, tempat bermain dan satuan Pendidikan Anak Usia Dini dengan cara: mengamati dengan indera (melihat, mendengar, menghirup, merasa, meraba), menanya; mengumpulkan informasi; menalar, dan mengkomunikasikan melalui kegiataan bermain, sebagai cerminan kemampuan pengetahuan dari peserta didik. Ketika anak sudah mulai mengenal dirinya, kelaurga, teman, guru dan lingkungan sekitarnya sebagai bentuk anak didik mendapatkan pengetahuan, dikembangkan melalui penanaman akhlak. yang mengandung nilai amaccangeng nenniya alempungeng (cakap dan jujur) dengan prinsip Macca na melempu pada intinya guru Taman Kanak-Kanak Aisyiyah Bustanul Athfal Palopo telah berusaha mengajarkan sejak dini kepada anak didik dengan metode pembiasaan mengajak anak untuk selalu jujur dalam perkataan, dan metode keteladanan yang dimulai dengan prilaku guru harus cakap dalam melakukan pembelajaran. Karena ciri manusia yang macca adalah mampu melakukan sesuatu, mampu mengemukakan pendapat, mampu mengatasi berbagai macam persoalan sehingga dipercaya sesasamanya, dibarengi dengan kejujuran. Pepatah bugis mengatakan Lempu na acca iyanaritu madeceng riparadekki riwatakalee, iyanaritu temmasserang Dewata SeuwaE. Artinya Kejujuran dan kepandaian paling baik ditanamkan dalam diri kita, yang tidak bercerai dengan Allah swt. Ditegaskan dalam QS at-Taubah/9: 119:

Terjemahnya: 
Hai orang-orang yang beriman bertakwalah kepada Allah, dan hendaklah kamu bersama orang-orang yang benar.

Allah memerintahkan untuk beriman dan bertakwa dan selalu bersama dengan orang-orang yang jujur artinya seorang anak dalam mencari teman, harus pintar memilih teman yang baik nantinya akan membawa kepada kebaikan dunia dan akhirat.

Kompetensi Inti-4 diharapkan agar anak didik menunjukkan yang diketahui, dirasakan, dibutuhkan, dan dipikirkan melalui bahasa, musik, gerakan, dan karya secara produktif dan kreatif, sebagai bentuk realisasi pengamalan kemampuan keterampilan peserta didik. Pengamalan nilai al-Islam Kemuhammadiyahan mengandung dalam menanamkan nilai akidah, ibadah, akhlak dan muamalah pada anak didik akan terjabarkan dengan perilaku anak didik Taman Kanak-Kanak Aisyiyah Bustanul Athfal Kota Palopo dalam bentuk sudah dapat menolong dirinya sendiri, menyambut orang tuanya dengan gembira, dapat melakukan berbagai kegiatan melompat, berlari, melompat, menangkap dengan menjaga keseimbangan, dapat bernyanyi dan bergerak dengan ekspresi yang tepat dan dapat memainkan berbagai permainan dengan baik.

Salah satu subjek menjelaskan bahwa penjabaran kompetensi kedalam kompetensi dasar merupakan hal yang penting dan menjadikan acuan dalam standar tingkat pencapaian perkembangan anak dalam berbagai aspek yakni aspek nilai-nilai agama dan moral, fisik motorik, bahasa, kognitif, dan seni, dalam melakukan pembelajaran untuk mencapai tujuan pendidikan.

Realisasi penerapan struktur program pembelajaran dalam bentuk sikap yang terbangun pada anak didik sesuai dengan kompetensi sikap spritual dan kompetensi sikap sosial, dan penanaman sikap dibangun melalui pembiasaan dan keteladanan. Hal tersebut yang membuat peneliti memunculkan suatu konsep pembelajaran, bahwa model pembiasaan dan keteladanan yang paling efektif digunakan dalam pencapaian tujuan pembelajaran di Taman Kanak-Kanak Aisyiyah Bustanul Athfal Kota Palopo karena berdampak positif terhadap perkembangan prilaku anak didik.

Menurut Sutrisno (2015) kewajiban guru memberi keteladanan dengan selalu berbicara jujur, tersenyum dan menjadi pendengar yang baik, sehingga bisa menjadi panutan bagi peserta didik, selanjutnya guru harus membuata suasana belajar yang menyenangkan dan dapat memberikan lingkungan belajar yang aman, nyaman, serta guru harus memahami bahwa perasaan dan sikap peserta didik akan terlibat dan berpengaruh kuat pada proses belajarnya.

Salah satu contoh rencana kegiatan mingguan dari bentuk kegiatan pembelajaran dengan tema diriku, dengan sub tema mengenal identitas diri, materinya terbiasa mengucapkan hamdalah sebagai rasa syukur terhadap Tuhan, terbiasa mengucapkan doa, terbiasa memelihara kebersihan diri, dengan strategi praktek langsung, bercerita kisah Rasul dalam al-Qur'an, bernyanyi dan pemberian

8 NANAEKE - Indonesian Journal of Early Childhood Education, Vol. 1, No. 1, Desember 2018 
tugas unTaman Kanak-Kanak melihat perkembangan anak dalam aspek nilai agama dan moral, fisik motorik dalam pencapaian tujuan pembelajaran yakni untuk mengetahui kemampuan anak mengucapkan kalimat pujian, dan mampu mengetahui prilaku hidup sehat dan mampu berprilaku baik, sopan santun sebagai cerminan prilaku akhlakul karimah.

Rencana kegiatan semester dan rencana kegiatan mingguan arahnya tidak terlepas dari tujuan kurikulum Aisyiyah yaitu menempuh pendidikan selanjutnya, mencakup kemampuan sikap, kemampuan pengetahuan, dan kemampuan keterampilan, sekaligus mendorong perkembangan peserta didik secara optimal sehingga memberi dasar untuk menjadi manusia Indonesia yang memiliki kemampuan hidup sehat sebagai pribadi yang beriman, produktif, kreatif, inovatif, dan efektif serta mampu berkontribusi pada kehidupan masyarakat, berbangsa, bernegara, dan peradaban dunia.

Taman Kanak-Kanak Aisyiyah mendesain rancangan kegiatan yang akan dilaksanakan dalam waktu satu hari yang diambil dari Rencana Pelaksanaan Pembelajaran Mingguan. Langkah-langkah dalam menyusun RPPH adalah disusunberdasarkan kegiatan mingguan, kegiatan harian berisi pembukaan inti dan penutup.Guru Taman Kanak-Kanak Aisyiyah dalam memulai kegiatan belajar, sebelum masuk kelas mereka terlebih dahulu menyusunkegiatan harian disesuaikan dengan kondisi satuan pendidikan masing-masing dan menggunakan pendekatan saintifik, tematik integrative, dalam mengembangkan indikator pencapaian pembelajaran. Media/sumber belajar dan metode disesuaikan dengan kegiatan pembelajaran yang akan dilaksanakan. Kegiatan harian dapat dibuat oleh satuan pendidikan dengan format sesuai dengan kebutuhan masing-masing. RPPH memuat kegiatan pembuka, inti, istirahat, dan kegiatan penutup.

Menurut Asmani (2011) strategi yang paling tepat untuk pencapaian karakter/akhlakul karimah, dengan metode keteladanan. Hakekat keteladanan dalam pendidikan merupakan bagian dari sejumlah metode yang paling efektif dalam mempersiapkan dan membentuk anak secara moral spritual dan sosial. Islam menjadikan Rasulullah saw sebagai suri tauladan yang baik bagi seluruh manusia. Hal ini disebuTaman Kanak-Kanakan dalam QS al-Ahzab/33:21:

Terjemahnya:

Sesungguhnya telah ada pada (diri) Rasulullah itu suri teladan yang baik bagimu (yaitu) bagi orang yang mengharap (rahmat) Allah dan (kedatangan) hari kiamat dan Dia banyak menyebut Allah.

Makna yang terkandung dari ayat di atas bahwa dalam kehidupan keluarga, setiap anak sangat membutuhkan suri teladan, khususnya dari orang tuanya agar sejak masa kanak-kanaknya ia menyerap dasar tabiat prilaku Islami dan berpijak pada landasannya yang luhur.

Data yang diberikan oleh Kepala Sekolah Taman Kanak-Kanak Aisyiyah 
Bustanul Athfal I Kota Palopo, menurut Hadijah (2018) berpendapat bahwa pada dasarnya sekolah ini sudah mengalami perkembangan baik dari segi jumlah murid, SDM tenaga pendidik/guru sudah linear, alat pembelajaran sudah hampir memadai, namun masih dibutuhkan operator dalam proses kelancaran pembelajaran Taman Kanak-Kanak Aisyiyah Bustanul Athfal I, begitupun dalam pelaksanakan pembelajaran telah menggunakan kurikulum dan model pembelajaran Taman Kanak-Kanak Aisyiyah Bustanul Athfal, diintegrasikan dengan al-Islam Kemuhammadiyahan untuk mencapai tujuan kurikulum.

Peneliti berkesimpulan bahwa sudah menjadi tanggung jawab dari kepala sekolah untuk memantapkan manajemen kurikulum dibantu oleh pendidik/guru dalam proses pelayanan Pendidikan Anak Usia Dini yang dilaksanakan baik dalam kelas maupun di luar kelas. Berbagai kegiatan kepala sekolah bersama dengan guru menyusun, kalender Pendidikan, menyusun RPPM dan RPPH, menyusun jadwal kegiatan layanan Pendidikan Anak Usia Dini bagi peserta didik, menetapkan strategi pelaksanaan pembelajaran dan tahap-tahap penilaian hasil belajar dan proses pembelajaran peserta didik secara kontinu, untuk mencapai tujuan kurikulum.

Guru Taman Kanak-Kanak Aisyiyah Bustanul Athfal II Kota Palopo, Nursyamsi (2018) berpendapat bahwa jadwal kegiatan pembelajaran yang berlangsung sebagai berikut: Pertama, proses pembelajaran di Taman Kanak-Kanak Aisyiyah berlangsung selama 6 hari, dari Senin sampai Sabtu, Kedua, setiap hari Senin Upacara Bendera, Ketiga pada hari Jum'at senam/Olah Raga bersama, Keempat, Pengembangan bakat, Praktek Wudhu, Praktek Sholat dan Hafalan surah-surah pendek dilaksanakan pada hari Sabtu, dan sekali dalam sebulan pemberian makanan bergizi. Jam belajar pukul 07.30 sampai 10.30 dimulai dalam bentuk berbaris (SOP), pembukaan, kegiatan inti, istirahat (bermain bebas di luar kelas, makan bersama, penutup. Jadwal tersebut diberlakukan dengan tujuan untuk memperlancar proses belajar mengajar para guru sehingga dengan mudah dapat menyusun rencana kegiatan mingguan dan rencana kegiatan harian sesuai dengan tema- tema yang akan diajarkan dari hari ke hari.

Pelaksanaan pembelajaran Taman Kanak-Kanak Aisyiyah Kota Palopo dengan model pembelajaran kelompok dengan kegiatan pengaman, RPPH berisikan kegiatan pendahuluan, kegiatan inti, diawali dengan kegiatan inti, kegiatan istirahat dan kegiatan penutup. Pelaksanaan kurikulum Taman Kanak-Kanak Aisyiyah yang diawali perencanaan pembelajaran dengan program semester.

Fatmawati berpendapat bahwa kurikulum Taman Kanak-Kanak Aisyiyah dalam dua semester memiliki lima ranah pengembangan, yaitu pengembangan nilai-nilai agama dan moral, pengembangan bahasa, pengembangan kognitif, pengembangan fisik motorik, dan pengembangan seni, dikembangkan dalam sebelas tema pembelajaran. Penggunaan tema dimaksudkan agar anak didik mampu mengenal berbagai konsep secara mudah dan jelas. Tema tersebut meliputi diri sendiri, keluargaku, lingkunganku, binatang, tanaman, kendaraan, alam semesta, dan 
negaraku.

Perencanaan pembelajaran dalam mengimplementasikan kurikulum dalam mencapai tujuan pendidikan. Segala sesuatu yang diperbuat di hari esok, haruslah direncanakan terlebih dahulu, terbukti dalam QS al-Hasyr/ 59:18:

Terjemahnya:

Hai orang-orang yang beriman, bertakwalah kepada Allah dan hendaklah Setiap diri memperhatikan apa yang telah diperbuatnya/direncanakan untuk hari esok (akhirat); dan bertakwalah kepada Allah, sesungguhnya Allah Maha mengetahui apa yang kamu kerjakan.

Hal tersebut menandakan bahwa setiap manusia yang beriman hendaknya selalu mempunyai persiapan terlebih dahulu sebelum melakukan kegiatan yang akan membawa manfaat bagi kesejahteraan manusia hidup di dunia dan di akhirat.

\section{SIMPULAN}

Berdasarkan hal tersebut peneliti mengemukakan kesimpulan sebagai berikut, perencanaan pembelajaran kurikulum Taman Kanak-Kanak Aisyiyah Bustanul Athfal Kota Palopo meliputi Rencana Kegiatan Semester, Rencana Kegiatan Mingguan dan Rencana Kegiatan Harian dan Evaluasi sebagai tahap akhir dalam penilaian hasil belajar anak didik dan alokasi waktu yang digunakan dalam 2 Semester selama 34 minggu merupakan program tahunan diuraikan dalam Tema Diriku, Keluargaku, Lingkungan, Binatang, Tanaman, Kendaraan, Alam Semesta, Negaraku dijabarkan ke dalam berbagai sub tema dalam berbagai lingkungan perkembangan anak meliputi aspek nilai agama dan moral, aspek sosial emosional, aspek kognitif, aspek

bahasa dan aspek seni terintegrasi dengan pendidikan al-Islam Kemuhammadiyahan melalui pendekatan kearifan lokal dalam menanamkan nilainilai akidah, ibadah, akhlak dan muamalah pada diri anak sejak usia dini.

\section{DAFTAR PUSTAKA}

Gani, A. dkk. (1990). Wasiat-Wasiat dan Lontara Bugis. Jakarta: Depdikbud.

Asmani, J.M. (2011). Internalisasi Pendidikan Karakter di Sekolah. Yogyakarta: Diva Press.

Daradjat, Z., dkk. (2008). Metodik Khusus Pengajaran Agama Islam. Edisi Kedua, Cet. IV; Jakarta: Bumi Aksara.

Haddade, M.N. (1986). Ungkapan Pribahasa dan Paseng. Jakarta: Depdikbud.

Hamalik, O. (2008). Manajemen Pengembangan Kurikulum. Bandung: PT Remaja Rosdakarya.

Kementerian Agama RI., (2012). Al-Qur'an dan Terjemahnya, Jakarta: Direktur 
Jenderal Bimbingan Masyarakat Islam Dirjen Urusan Agama Islam dan Keluarga Sakinah.

Muflihin, M.H. (2015). Administrasi Pendidikan. Klaten: Gema Nusa.

PP. Aisyiyah Majelis Dikdasmen (2012). Kurikulum, Pedoman dan Model Pembelajaran Pendidikan Anak Usia Dini Aisyiyah. Yogyakarta: PP Muhammadiyah

Sutrisno. (2015). Revolusi Pendidikan Indonesia. Yogyakarta: Ar-ruzz Media.

Tarazi, N. (2003). The Child In Islam: a Muslim Parent's Handbook, terj. Nawang Sri Wahyuningsih, Wahai Ibu Kenali Anakmu: Pegangan Orang tua Muslim Mendidik Anak. Bandung: Mitra Pustaka.

Trianto. (2011). Desain Pengembangan Pembelajaran Tematik Bagi Anak Usia Dini Taman Kanak-Kanak/RA \& Anak Kelas Awal SD/MI (edisi pertama). Jakarta: Kencana. 